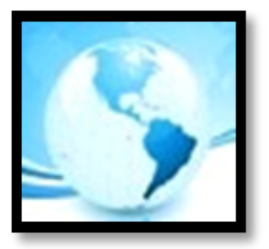

MALAYSIAN ONLINE JOURNAL OF

EDUCATIONAL MANAGEMENT

(MOJEM)

April 2020, VOLUME 8, ISSUE 2, 59-71

E-ISSN NO: $2289-4489$

\title{
EXPLORING QUALITY OF STUDENT SERVICES OF A PHILIPPINE STATE UNIVERSITY SATELLITE CAMPUS USING SERVQUAL AND SERVICE IMPROVEMENT MATRIX
}

Melvin S. Sarsale ${ }^{1}$ \& Sherwin G. Caday ${ }^{2}$

[1] College of Business and

Management,

Southern Leyte State University,

San Juan, Southern Leyte,

Philippines

[2] College of Aquatic and Applied

Life Sciences,

Southern Leyte State University,

Bontoc, Southern Leyte,

Philippines

Corresponding Author:

College of Business and

Management

E-mail: melvin.sarsale@yahoo.com

\begin{abstract}
The growing competition in higher education which traverse beyond boarders have urged universities and colleges to put premium on its quality service as it directly relates to student's satisfaction and dissatisfaction. In this paper, the quality of student services of a university was assessed using SERVQUAL model and priorities for improvement were identified using service improvement matrix. The data were gathered from 175 students enrolled in one of the satellite campuses of a Philippine state university using a validated modified service quality assessment survey instrument. The data were analyzed using descriptive statistics, gap analyses and service improvement matrices. The findings revealed that quality of students' services generally fell short of students' expectations across all indicators, servicing units and dimensions of which responsiveness showed the highest negative gap while tangibles got the lowest negative gap among all dimensions. Service improvement matrices were developed by plotting students' expectations and experiences and revealed improvement priorities that will then the basis of the university in instituting reforms so as to address these negative gaps.
\end{abstract}

Keywords: Service Quality, Tangibles, Reliability, Responsiveness, Assurance, Empathy 


\section{MALAYSIAN ONLINE JOURNAL OF EDUCATIONAL MANAGEMENT (MOJEM)}

\section{INTRODUCTION}

The drive for internationalization of higher education in the Philippines has urged universities and colleges to put premium on its quality service as it directly relates to student's satisfaction and dissatisfaction especially that the growing competition is now traversing beyond boarders. Philippine universities and colleges have long since confronted uneven quality of education as evidenced in the world rankings which featured only four universities from the country (Ortiga, 2018). Higher education has been increasingly regarded as service industry, thus putting more importance on addressing clients' needs and expectations in order to get the desired position and share in the student market (Chui, Ahmad, Bassim, \& Zaimi, 2016). In the Philippines, the government is strengthening its service delivery to the Filipinos by requiring ISO certification of all its agencies including state universities and colleges on its quality management systems. In this context, service quality is not just essential in all colleges and universities but a direct mandate from the government.

The services of the university would be considered to be of quality, if the university's products and processes satisfy the needs and expectations of the students and other stakeholders (Datta \& Vardhan, 2017). Understanding student's perception towards service quality is very important for colleges and universities, as the student's involvement is so critical in making the service successful (Chui et al., 2016; Hill, 1995). A number of literature revealed several models in gauging service quality however SERVQUAL model (Parasuraman, Zeithaml, \& Berry, 1988) has known to be the most used by scholars and practitioners (Amin, Yahya, Ismayatim, Nasharuddin, \& Kassim, 2013; Yarimoglu, 2014; Ghotbabadi, Feiz, \& Baharun, 2015; Tefera \& Govender, 2016; Ojaghi, Rezaee, Naderi, \& Jafari, 2017) and has been extensively applied in different faces of the service industry except for higher education sector which only few studies have been conducted (Datta \& Vardhan, 2017). This model provides a validated instrument that can measure five service quality dimensions in different situations (Rohini \& Mahadevappa, 2006).

Although a limited application of this model among higher education services has been observed in the Philippines (Cayanan, 2017), only a handful of researches had focused on student-related services. This gap had provided an opportunity for this study to apply this model in order to investigate the quality of student-related services of a university. Previous studies outlined the importance of student support in improving student persistence (Arifin, 2018). In fact, the Commission on Higher Education, being the oversight agency of higher education institutions in the country, issued a memorandum that emphasized on providing better quality student services. Moreover, providing support to the social and emotional along with the academic needs of the students can help significantly in augmenting quality of higher learning (Kaur, 2016).

SERVQUAL model utilizes gap analysis technique in measuring service quality in which the gap is identified by deducting the perceived experience from expectation (Parasuraman et al.,1985). Though the gap is noted in each dimension, it does not provide the concerned organization which service quality dimension should be prioritized for improvement. In other words, the model alone cannot suggest order of priorities in addressing gaps in all dimensions especially that prioritization is very essential to learning institutions with meager resources. Conversely, this limitation can be addressed with the emergence of service improvement matrix model. This analytical tool creates a plot between expectation measured as to importance and experience based on student's satisfaction. This matrix enables decision makers to see and understand which particular quadrant that each service quality dimension fall under and be able to prioritize what dimension should be improved first (Chui et al., 2016).

Using the SERVQUAL and service improvement matrix models, a university will be able to gauge its quality as well as to address which aspect of quality should be given with preferential attention. This assessment is the most proactive way of getting direct feedbacks regarding the student's life in the university. Furthermore, the university can mirror on the satisfaction of the students the way they provide the student services and eventually strategize and institute reforms in order to increase delighted clienteles. 


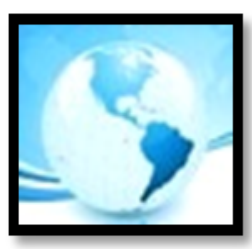

\section{OBJECTIVES OF THE STUDY}

This study was conducted to assess the quality of student services of a satellite campus of a Philippine state university using SERVQUAL and service improvement matrix.

Specifically, it aimed to: (1) describe quality of student services of a university using the five dimensions of service quality namely, tangible, reliability, responsiveness, assurance and empathy based on student's expectation and experience; (2) conduct a gap analysis on the quality of student services for each indicator, servicing unit and dimensional level; and (3) develop service improvement matrices that set improvement priorities among indicators, servicing units and dimensions.

\section{METHODS}

\section{Research Environment}

This study was conducted in one of the satellite campuses of one of the leading Philippine state universities in Eastern Visayas. This university campus currently offers programs in agriculture and fisheries and its allied fields. Just like a typical university campus in the country, it has a unit collectively known as office of student affairs and services that provide a set of student centered activities and services in support of academic instruction (CHED, 2013). This unit is comprised of student welfare services, student development services and institutional student programs and services. However, only the basic units of student services are included in this study such as the canteen, clinic, dormitory, guidance, and other student services as provided by the head of the unit as these services are considered to be critical to the life of the students in the university.

\section{Research Respondents}

The respondents of this study were the students of the university campus, however, only those students in their $2^{\text {nd }}$ year and above were considered in the study as these students had stayed in the university for at least one year and, thus, were in the best position to describe their experiences in the university. Only $72.51 \%(175 / 242)$ of the target respondents had actually participated in the study.

\section{Research Instrument}

The primary data needed for this study were gathered using an adopted service quality assessment survey instrument (Chui et al., 2016). However, it has been modified so as to contextualize with the current settings of the study along with unstructured interviews among some of the respondents for the purpose of clarifying their responses or answering their queries regarding certain aspects of the questionnaire. This instrument has two parts, of which the first part describes the expectations of the students of a quality student services should be possessed by a university which is rated as to its importance using a 6-point Likert scale (1-unimportant to 6-extremely important) while the second part describes the actual experiences of the students as what had provided by the university which is measured using 6-point Likert scale (1-strongly disagree to 6 strongly agree). A total of same 17 indicators describing the five dimensions of service quality were used in each part.

A dry run procedure was conducted among students who were not included in the actual study to determine reliability of the modified instrument using Cronbach's Alpha (Cronbach, 1951; Tavakol \& Dennick, 2011). The result of the Cronbach's alpha was 0.934 which indicates a high level of reliability. Consequently, the questionnaire was finalized for administration. 


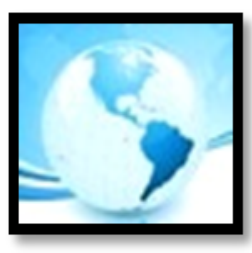

MALAYSIAN ONLINE JOURNAL OF

EDUCATIONAL MANAGEMENT

(MOJEM)

Data Collection Technique

Before the administration of the instrument, an authority from the campus director was sought. Each questionnaire has a letter from the researchers explaining the nature and purpose of each set of questions. The researchers were present throughout the duration of accomplishment of the questionnaire by the respondents to answer whatever queries they may raise and to clarify some terms in the instruments whenever the need arises.

\section{Data Analyses}

The data gathered from the instrument were subjected to three types of gap analysis as way of describing service quality of the student services of the university. In this study, gap was basically computed by getting the difference between student's perceived rating on experiences and expectations which were further measured using weighted means and t-test. The first gap analysis was done per indicator level with the end view of analyzing which particular indicator scored the major gaps. The second gap analysis was performed on unit level basis to determine which particular unit of student services experienced high gaps. The last gap analysis was made on a dimensional level so as to explain what specific dimensions of service quality should the university need to improve.

For purposes of having a definite interpretation for each indicator, each mean rating was interpreted as extremely important/strongly agree $(\mu=5.20-6.00)$, very important/agree $(\mu=4.36-5.19)$, important/slightly agree $(\mu=3.53$ 4.35), moderately important/slightly disagree $(\mu=2.68-3.51)$, less important/disagree $(\mu=1.84-2.67)$ and unimportant/strongly disagree $(\mu=1.00-1.83)$. On the other hand, each dimension of service quality is clearly defined as follows based on what had been forwarded by Parasuraman et al. (1988) for the purpose of arriving the same meaning. Tangible refers to the physical appearance of the equipment, facilities and communication materials provided as well as on the personnel involved. Reliability refers to the ability of student services personnel to provide the needed services as promised dependably and accurately. Responsiveness refers to the enthusiasm of the staff to serve the students promptly. Assurance is refers on how the staff projects courtesy, trustworthiness and confidence in serving the students. Empathy refers on how the staff provides caring, individualized attention to the students.

Meanwhile, to determine which particular indicator, unit and dimension should be prioritized to be addressed by the university, a service improvement matrix was developed by plotting expectation (importance) versus experience (satisfaction) in a graph. Using the median in each axis as means of dividing the plot into four quadrants, the graph can clearly depict which particular quadrant that each indicator, unit and dimension fall. The first quadrant shows the strengths of the university which means that the students rated high both their expectations and experiences on student services quality. The second quadrant displays student services for redeployment as the students rated higher in their experiences than their expectations. The third quadrant shows the opportunities of the university as the students scored low both in their expectations and experiences. The fourth quadrant presents what the university should prioritize for improvement as the students scored higher in their expectations than their experiences which can also be interpreted that the services of the university had fall short of the student's expectations.

In this study, three service improvement matrices were developed to reflect the three gap analyses made specifically for the indicator, unit and dimensional levels.

\section{Ethical Considerations}

To observe the proper protocols in conducting this study, prior written permissions were sought from the campus director. The questionnaire contains a message asking for the active participation of the respondents at their own option and it also state that their anonymity, confidentiality and neutrality will be kept. Proper citations were done for all the information and previous researches used in this study. 


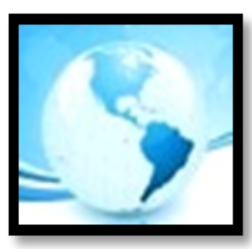

\section{RESULTS AND DISCUSSIONS}

\section{Gap Analysis on the Quality of Student Services Using SERVQUAL Indicators}

Table 1 presents the gap analysis made on the quality of student services using the 17 SERVQUAL indicators. As reflected in the table, the highest negative gap of 1.05 is noted between the expectations of students against their experiences on how the staff are performing the services fast. This implies that the students found the actual services to be slower than what they expect from the staff. Similarly, the student found disagreement from what they expect and experience regarding the employment of modern equipment in the student services offices as evidenced by its negative gap of 1.02. A negative gap of 1.01 have been experienced by students on how the staff are always ready to respond to any queries and on how the staff are never too busy to respond to student's request. On the lighter side, the lowest negative gap of 0.69 was noted on how the campus provides visually appealing facilities in all student services offices which means that there is a little dissatisfaction was felt by the students on this indicator. On average, the negative gap for all the SERVQUAL indicators is 0.92.

Table 1

Item gap analysis of service quality using SERVQUAL indicators

\begin{tabular}{|c|c|c|c|c|c|c|c|c|c|c|}
\hline \multirow{2}{*}{\multicolumn{2}{|c|}{ Indicators }} & \multicolumn{3}{|c|}{ Expectations } & \multicolumn{3}{|c|}{ Experiences } & \multirow{2}{*}{ Gap } & \multirow{2}{*}{ t-value } & \multirow{2}{*}{$p$-value } \\
\hline & & WM & AR & SD & WM & AR & SD & & & \\
\hline & $\begin{array}{l}\text { The campus provides the student } \\
\text { services as promised. }\end{array}$ & 4.78 & VI & 1.14 & 3.91 & SIA & 1.33 & -0.87 & 7.796 & $0.000 * *$ \\
\hline 2. & $\begin{array}{l}\text { The campus provides visually } \\
\text { appealing facilities in all student } \\
\text { services offices. }\end{array}$ & 4.61 & VI & 1.19 & 3.92 & SA & 1.24 & -0.69 & 6.669 & $0.000 * *$ \\
\hline 3. & $\begin{array}{l}\text { The staff of student services offices } \\
\text { are neat and professional. }\end{array}$ & 4.98 & VI & 1.12 & 4.13 & SA & 1.31 & -0.85 & 8.041 & $0.000 * *$ \\
\hline 4. & $\begin{array}{l}\text { The student services offices have } \\
\text { employed modern equipment. }\end{array}$ & 4.78 & VI & 1.08 & 3.76 & SA & 1.32 & -1.02 & 9.474 & $0.000 * *$ \\
\hline 5. & $\begin{array}{l}\text { The equipment in each office are } \\
\text { functioning well. }\end{array}$ & 4.86 & VI & 1.17 & 3.90 & SA & 1.32 & -0.95 & 8.638 & $0.000 * *$ \\
\hline 6. & $\begin{array}{l}\text { The staff are implementing student } \\
\text { charters, rules and regulations well. }\end{array}$ & 5.06 & VI & 1.14 & 4.14 & SA & 1.26 & -0.92 & 9.445 & $0.000 * *$ \\
\hline 7. & $\begin{array}{l}\text { The staff are dependable in } \\
\text { handling services-related problems. }\end{array}$ & 4.82 & VI & 1.07 & 4.01 & SA & 1.36 & -0.81 & 7.739 & $0.000 * *$ \\
\hline 8. & $\begin{array}{l}\text { The staff are always ready to } \\
\text { respond to any queries. }\end{array}$ & 4.99 & VI & 0.98 & 3.98 & SA & 1.43 & -1.01 & 9.007 & $0.000 * *$ \\
\hline 9. & $\begin{array}{l}\text { The staff are performing the } \\
\text { services fast. }\end{array}$ & 4.89 & VI & 1.07 & 3.84 & SA & 1.37 & -1.05 & 9.596 & $0.000 * *$ \\
\hline & $\begin{array}{l}\text { The staff are never too busy to } \\
\text { respond to student's request. }\end{array}$ & 4.90 & VI & 1.13 & 3.89 & SA & 1.33 & -1.01 & 9.030 & $0.000 * *$ \\
\hline & $\begin{array}{l}\text { The staff are very prompt in } \\
\text { providing services. }\end{array}$ & 4.90 & VI & 1.09 & 4.03 & SA & 1.31 & -0.87 & 7.897 & $0.000 * *$ \\
\hline & $\begin{array}{l}\text { I have trust and confidence with } \\
\text { the staff. }\end{array}$ & 5.03 & VI & 1.01 & 4.13 & SA & 1.36 & -0.90 & 8.681 & $0.000 * *$ \\
\hline & $\begin{array}{l}\text { I am assured that the staff are } \\
\text { knowledgeable in their jobs. }\end{array}$ & 5.09 & VI & 1.04 & 4.17 & SA & 1.44 & -0.92 & 8.451 & $0.000 * *$ \\
\hline 14. & $\begin{array}{l}\text { I am assured that services provided } \\
\text { by the office are accurate and each }\end{array}$ & 5.06 & VI & 0.99 & 4.11 & SA & 1.38 & -0.94 & 9.065 & $0.000 * *$ \\
\hline
\end{tabular}


confidentiality.

15. The staff provide each student with preferential attention.

\begin{tabular}{lllllllll}
4.97 & VI & 0.99 & 4.05 & SA & 1.31 & -0.93 & 9.058 & $0.000^{* *}$ \\
4.89 & VI & 0.99 & 3.97 & SA & 1.30 & -0.93 & 9.357 & $0.000^{* *}$ \\
4.99 & VI & 1.03 & 4.08 & SA & 1.40 & -0.91 & 7.695 & $0.000^{* *}$ \\
\hline 4.92 & VI & 0.12 & 4.00 & SA & 0.12 & -0.92 & 43.490 & $0.000^{* *}$
\end{tabular}

16. The campus offers convenient hours of operation.

17. The campus offers appropriate services and resources.

Overall Mean

4.92

ee $(S D) ;$

1.84-2.67 - Less Important (LI) / Disagree (DA);

2.68-3.51 - Moderately Important (MI) / Slightly Disagree (SDA); 3.52-4.35 - Important (I) / Slightly Agree (SA); 4.36-5.19 - Very Important (VI) / Agree (A); 5.20-6.00 - Extremely Important (EI) / Strongly Agree (STA); ns - not significant; * - significant; ** - highly significant

Meanwhile, the students were assured that the staff are knowledgeable in their jobs and thus rated it with highest expectation $(\mu=5.09)$ and with highest satisfaction $(\mu=4.17)$. The indicators such as being assured that services provided by the office are accurate and each transaction will be treated with utmost confidentiality and the staff are implementing the student charters, rules and regulations well were rated with higher expectations $(\mu=5.06)$. On the other hand, the students have the lowest expectation on the provision of the campus with visually appealing facilities in all its student services offices $(\mu=4.61)$. In terms of student's actual experience of these indicators, they rated the lowest on the utilization of modern equipment in the student services offices ( $\mu=3.76)$. As presented in the table, there were significant gaps among indicators which mean that student services provided by the campus fell short as revealed from the difference between the student's actual experience and expectation.

\section{Gap Analysis on the Quality of Student Services by Servicing Units}

Table 2 shows the gap analysis conducted on selected student services units using the five SERVQUAL dimensions. It is noteworthy to mention that canteen has reflected the highest negative gaps almost in all dimensions as the students considered this to be the least important $(\mu=4.67)$ and most dissatisfying unit $(\mu=2.90)$. This clearly shows that canteen as a servicing unit was poorly rated by the students. This result corroborates to the study made by Bugnalen, Orsal, Sarmiento, and Tomas (2009) on the satisfaction level of stakeholders on the service units of a Philippine private university in which canteen was the least rated. Furthermore, Cadag (2017) also found food and dining services as not effective in a public state university which needs further improvement. The same result was also noted to the dormitory services of the campus in which all dimensions earned higher negative gaps.

Table 2

Unit level gap analysis of service quality using SERVQUAL dimensions

\begin{tabular}{|c|c|c|c|c|c|c|c|c|c|c|}
\hline \multirow{2}{*}{$\begin{array}{l}\text { Student } \\
\text { Services }\end{array}$} & \multirow[b]{2}{*}{ Dimensions } & \multicolumn{3}{|c|}{ Expectations } & \multicolumn{3}{|c|}{ Experiences } & \multirow[b]{2}{*}{ Gap } & \multirow[b]{2}{*}{ t-value } & \multirow[b]{2}{*}{ p-value } \\
\hline & & WM & AR & SD & WM & $A R$ & SD & & & \\
\hline \multirow{5}{*}{ Canteen } & Tangibles & 4.42 & VI & 0.12 & 2.98 & SDA & 0.19 & -1.44 & 10.385 & $0.002 * *$ \\
\hline & Reliability & 4.75 & VI & 0.14 & 3.13 & SDA & 0.18 & -1.62 & 60.464 & $0.000 * *$ \\
\hline & Responsiveness & 4.67 & VI & 0.18 & 2.73 & SDA & 0.13 & -1.95 & 13.627 & $0.001 * *$ \\
\hline & Assurance & 4.79 & VI & 0.15 & 2.84 & SDA & 0.12 & -1.95 & 13.683 & $0.005^{* *}$ \\
\hline & Empathy & 4.71 & VI & 0.10 & 2.81 & SDA & 0.17 & -1.90 & 12.764 & $0.006 * *$ \\
\hline
\end{tabular}




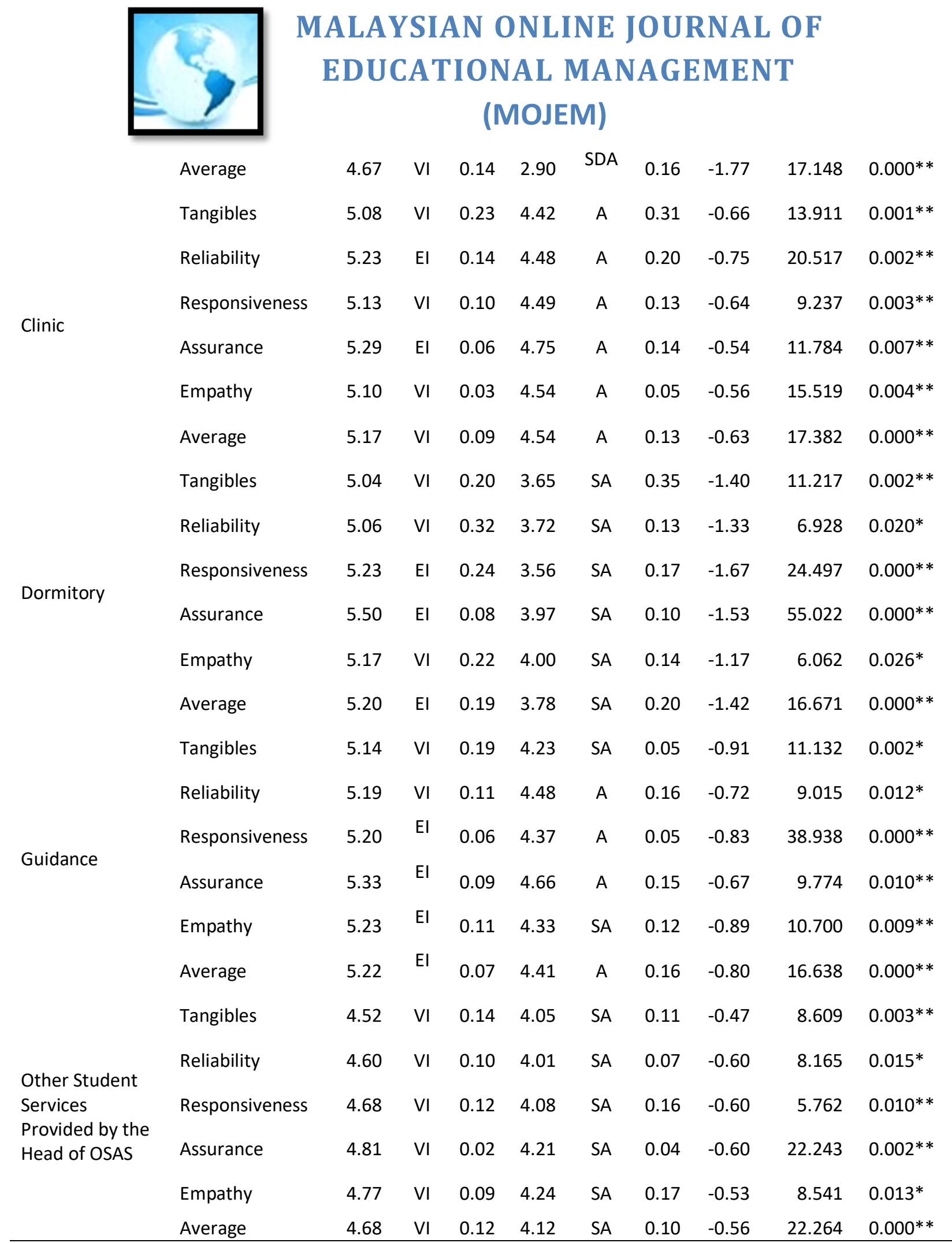

Legend: 1.00-1.83 - Unimportant (UI) / Strongly Disagree (SD); 1.84-2.67 - Less Important (LI) / Disagree (DA); 2.68-3.51 - Moderately Important (MI) / Slightly Disagree (SDA); 3.52-4.35 - Important (I) / Slightly Agree (SA); 4.36-5.19 - Very Important (VI) / Agree (A); 5.20-6.00 - Extremely Important (EI) / Strongly Agree (STA); ns - not significant; * - significant; ** - highly significant 


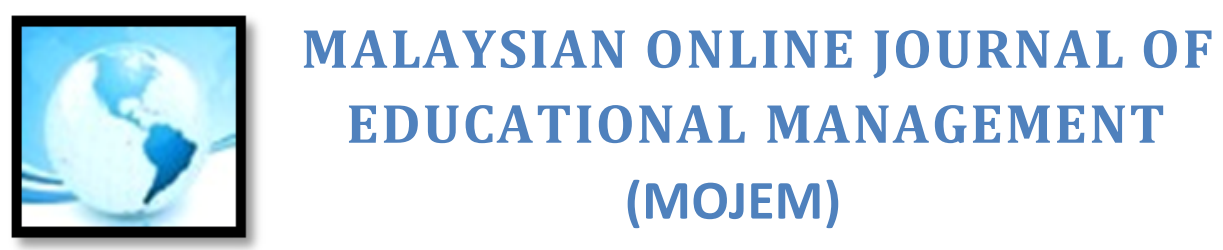

On the other hand, other services provided by the head of the student affairs and services received the lowest negative gap among all the servicing units. This may connote that the students' expectations were almost met by this particular unit. The clinic also showed a lower negative gap and the highest satisfaction rating compare to the other servicing units as which may imply that this unit had significantly responded to student's needs. This result corroborates to a study by Ibarrientos (2015) which revealed that that it found effectiveness of medical and dental services program of a polytechnic college especially when it is staffed with qualified and experienced personnel who always make ready the services available to the students. Afterwards, the students rated the guidance unit with highest importance among all the units $(\mu=5.22)$, followed by the dormitory $(\mu=5.20)$. As reflected in the table, significant gaps did exist across all servicing units based on the experiences and expectations of the students.

\section{Gap Analysis on the Quality of Student Services Using SERVQUAL Dimensions}

Table 3 portrays the gap analysis on dimensional level. The average negative gap among all dimensions is 0.92 . The students rated the highest expectation with $(\mu=5.06)$ and the highest satisfaction rating $(\mu=4.14)$ on assurance. Based on the table, the students had lesser expectations $(\mu=4.79)$ and the lowest satisfaction rating $(\mu=3.93)$ on tangibles than the rest of the dimensions. Generally, all dimensions experienced negative gaps which supported to Cayanan (2017) who argued that private schools revealed a prevalent negative service quality gaps or feelings of dissatisfaction across five dimensions. Conversely, all dimensions have significant gaps as assessed by the students.

Table 3

Gap analysis on the quality of student services using SERVQUAL dimensions

\begin{tabular}{|c|c|c|c|c|c|c|c|c|c|}
\hline \multirow{2}{*}{$\begin{array}{l}\text { Service Quality } \\
\text { Dimensions }\end{array}$} & \multicolumn{3}{|c|}{ Expectations } & \multicolumn{3}{|c|}{ Experiences } & \multirow{2}{*}{ Gap } & \multirow{2}{*}{ t-value } & \multirow{2}{*}{ p-value } \\
\hline & WM & AR & SD & WM & AR & SD & & & \\
\hline Tangibles & 4.79 & $\mathrm{VI}$ & 0.15 & 3.93 & SA & 0.15 & -0.86 & 12.704 & $0.001 * *$ \\
\hline Reliability & 4.91 & VI & 0.13 & 4.02 & SA & 0.12 & -0.90 & 19.995 & $0.002 * *$ \\
\hline Responsiveness & 4.92 & VI & 0.05 & 3.93 & SA & 0.08 & -0.99 & 24.952 & $0.000 * *$ \\
\hline Assurance & 5.06 & VI & 0.03 & 4.14 & SA & 0.03 & -0.92 & 63.548 & $0.000 * *$ \\
\hline Empathy & 4.95 & VI & 0.05 & 4.03 & SA & 0.06 & -0.92 & 275.000 & $0.000 * *$ \\
\hline Average & 4.93 & VI & 0.10 & 4.01 & SA & 0.09 & -0.92 & 42.433 & $0.000 * *$ \\
\hline
\end{tabular}

Legend: 1.00-1.83 - Unimportant (UI) / Strongly Disagree (SD); 1.84-2.67 - Less Important (LI) / Disagree (DA); 2.68-3.51 - Moderately Important (MI) / Slightly Disagree (SDA); 3.52-4.35 - Important (I) / Slightly Agree (SA); 4.36-5.19 - Very Important (VI) / Agree (A); 5.20-6.00 - Extremely Important (EI) / Strongly Agree (STA); ns - not significant; * - significant; ** - highly significant

\section{Service Improvement Matrix Using SERVQUAL Indicators}

Figure 1 depicts the created service improvement matrix by plotting the expectations (importance) and experiences (satisfaction) based on the students' rating on each indicator with the end view of determining what particular indicators should be prioritized for improvement.

As reflected in the figure, the staff are always ready to respond to any queries and are never too busy to respond to student's request fell on the fourth quadrant which means that these are considered to be prioritized for improvement. On the other hand, the matrix considers the following indicators as the strengths of the campus as 


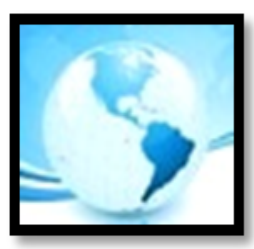

these fell on the first quadrant namely, having neat and professional staff, implementing student charters, rules and regulations well, having trust and confidence with the staff, having knowledgeable staff of their jobs, being assured of the accuracy of the services with utmost confidentiality, giving individual attention and offering appropriate services and resources. However, the figure clearly shows various opportunities as these indicators fell in the third quadrant such as providing the services promised, having visually appealing facilities and functional modern equipment, dependability of staff in handling service problem, performing services fast, and providing convenient hours of operation.

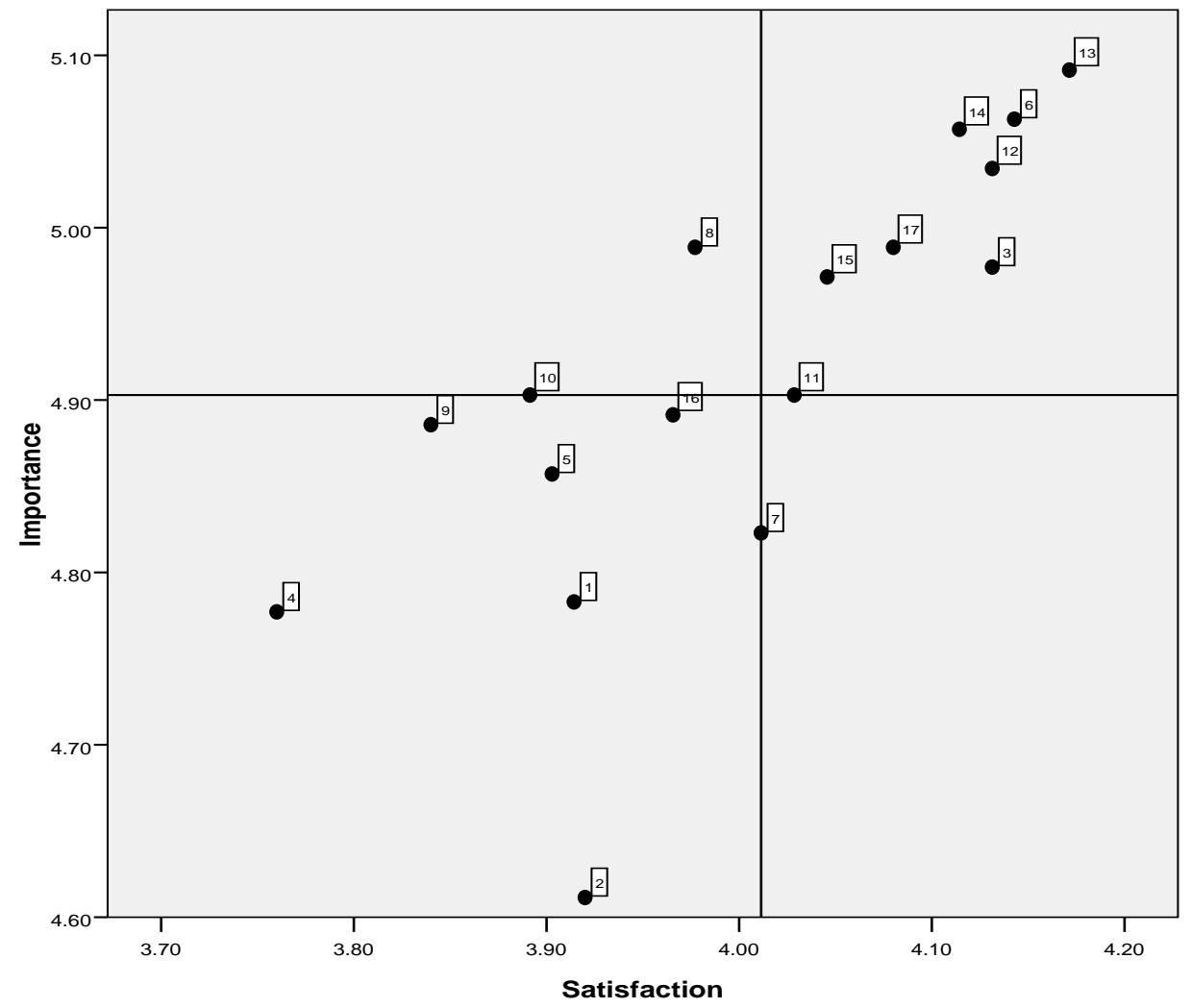

Legend: 1. The campus provides the student services as promised.

2. The campus provides visually appealing facilities in all student services offices.

3. The staff of student services offices are neat and professional.

4. The student services offices have employed modern equipment.

5. The equipment in each office are functioning well.

6. The staff are implementing student charters, rules and regulations well.

7. The staff are dependable in handling services-related problems.

8. The staff are always ready to respond to any queries.

9. The staff are performing the services fast.

10. The staff are never too busy to respond to student's request.

11. The staff are very prompt in providing services.

12. I have trust and confidence with the staff.

13. I am assured that the staff are knowledgeable in their jobs.

14. I am assured that services provided by the office are accurate and each transaction is treated with utmost confidentiality.

15. The staff provide each student with preferential attention.

16. The campus offers convenient hours of operation.

17. The campus offers appropriate services and resources.

Figure 1. Service improvement matrix using SERVQUAL indicators 


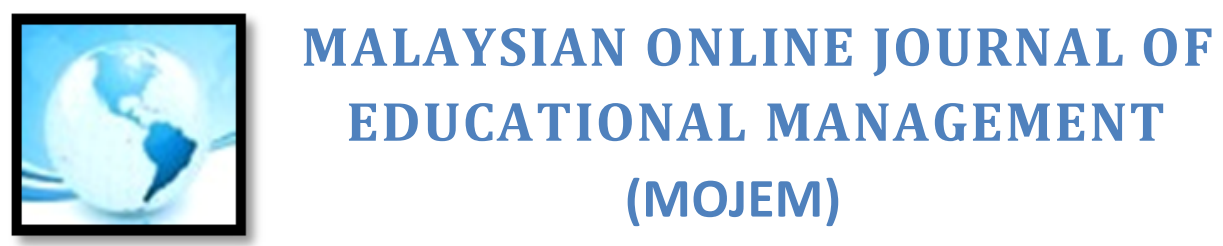

Service Improvement Matrix by Servicing Units

Figure 2 illustrates the generated service improvement matrix by plotting expectations and experiences per dimension per servicing unit. As shown in the figure, the dormitory is considered to be highest in priority for improvement. The students rated the dormitory with the highest importance but with lower satisfaction. Eisma (2017) stressed in her study on the need to give much attention and improvement on the student housing area as it garnered the lowest rating among students. Arangote (2018) also found lowest score in student housing and residential services in a state university.

Clinic and guidance units were classified as strengths of the campus. On the other hand, the canteen got the lowest importance and satisfaction which can be seen as an opportunity of the campus. Other student services provided by OSAS head fell on the redeployment quadrant which means that continue the way that these services are being provided to the students as these were rated with high satisfaction from the students but with low importance.

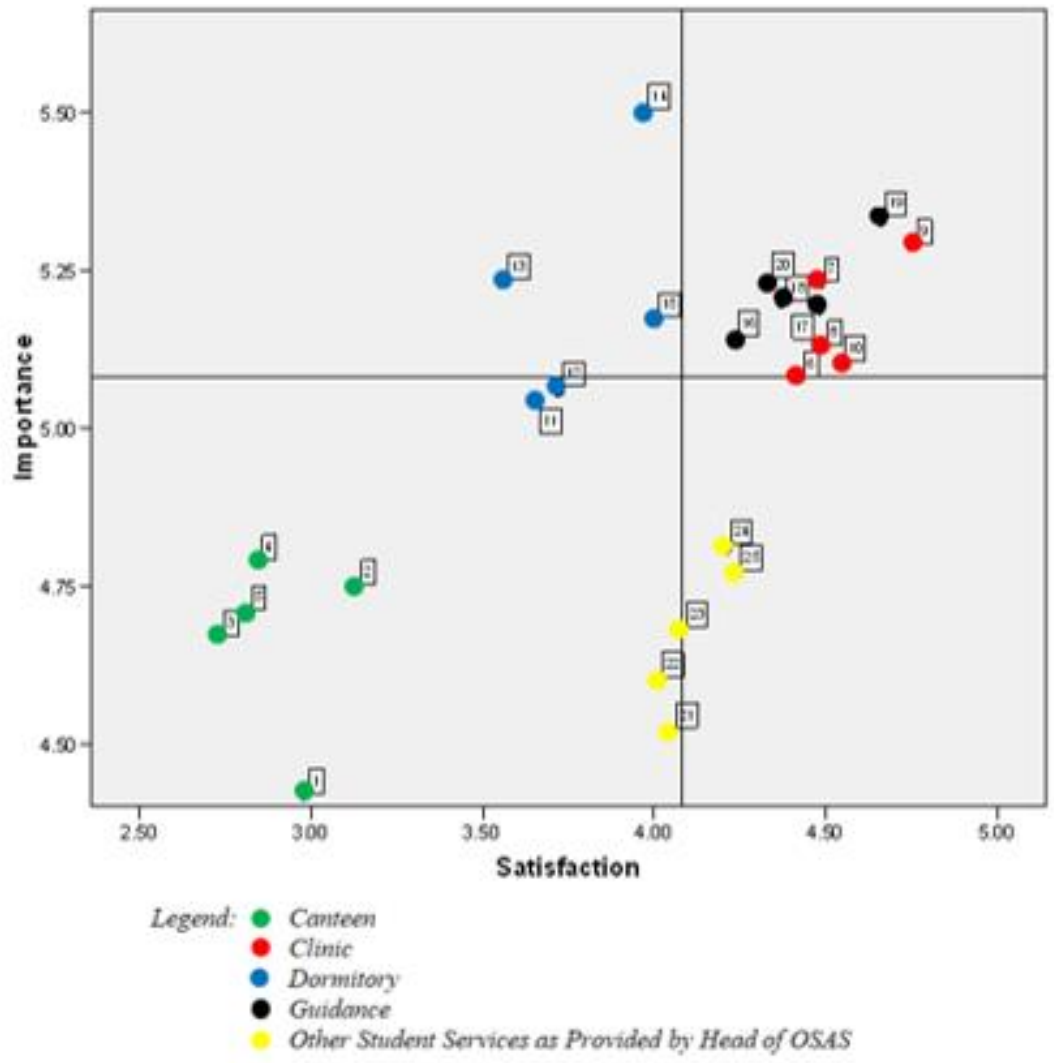

Figure 2. Service improvement matrix on a unit level basis

\section{Service Improvement Matrix on a Dimensional Level}

Figure 3 shows the service improvement matrix developed using the five SERVQUAL dimensions. The figure clearly provides that responsiveness should be given priority by the university for improvement. Same recommendation was suggested by Luna (2015) that the university should improve the quality of its services especially in effectively responding to the needs of the students by proving additional personnel as well as enhancement of its facilities. 


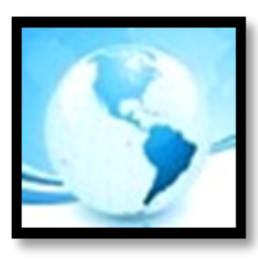

\section{MALAYSIAN ONLINE JOURNAL OF EDUCATIONAL MANAGEMENT (MOJEM)}

Assurance and empathy were the strengths of the campus. This means that the students are assured of the student services provided by the campus. Tangible fell on the opportunities section which means that the university may explore on improving the physical features of the university so as to increase its importance to the students which will eventually likewise increase their satisfaction level. Reliability fell on the redeployment quadrant which simply connotes that the services provided by the university were reliable and dependable. This also means that the students rated this particular dimension with lower importance but with higher satisfaction.

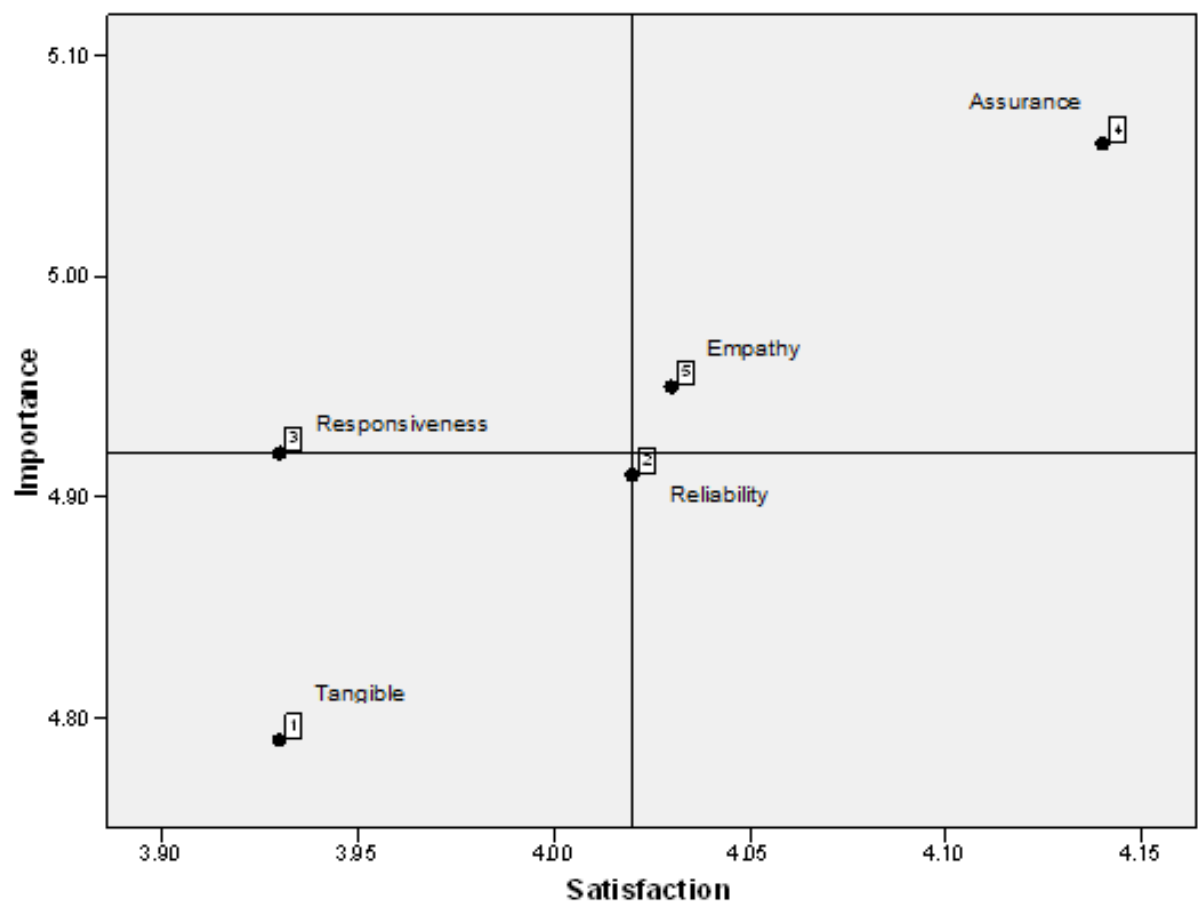

Figure 3. Service improvement matrix using SERVQUAL dimensions

\section{Comparing Findings with Contemporary Studies}

The quality of students services showed significant gaps across all dimensions which implies that the students' expectations of quality student services were not met based on their experiences. These negative gaps were also found in other studies (Cayanan, 2017; Datta \& Vardhan, 2017; Gregory, 2019; Milojević \& Radosavljević, 2019; Soares, Novaski, \& Anholon, 2017). In this particular study, responsiveness exhibited the highest negative gaps which corroborates to the results of Afridi, Khattak, and Khan (2016), and Misaii and Mohammadimehr (2018). On the other hand, some relevant studies also revealed assurance (Datta \& Vardhan, 2017; Rezaei et al., 2017), tangibility (Kalam \& Mahonta, 2017), and empathy (Chui et al., 2016) as the most dissatisfied dimension of service quality. Moreover, responsiveness emerged in this study as the most priority for improvement which contradicts to other studies suggesting reliability and tangibility (Lodesso, van Niekerk, Jansen, \& Müller, 2018) and empathy (Chui et al., 2016) as topmost priority for improvement. These results simply connote varying perceptions of students toward service quality as well as the level of service delivery among learning institutions across the world.

\section{CONCLUSIONS AND RECOMMENDATIONS}

Based on the findings of the study, the concepts on service quality and service improvement matrix evidently provide the quality of the student services of the university as well as on what to be prioritized which clearly show the applicability of these concepts in measuring quality of student-related services. 


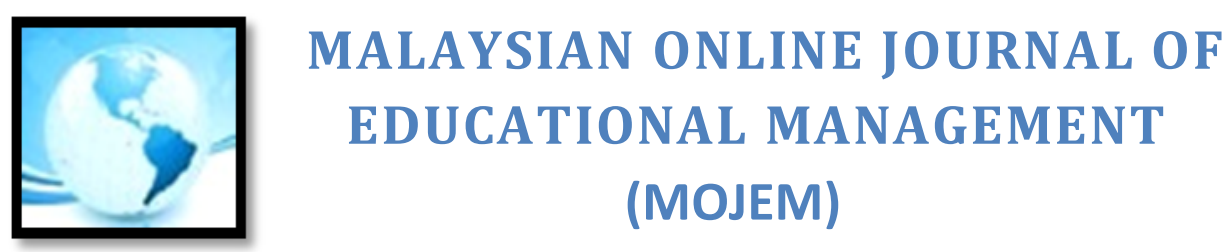

Generally, the quality of student's services of the campus fell short of the students' expectations of what the university should provide based on the gap analyses made per indicator, servicing unit and dimensional levels. The highest shortfall was noted among all indicators in the inability of the personnel to perform the services fast which means that the processing time is long enough so as this service is well appreciated among the students. Likewise, canteen was the most poorly rated unit which means that the students were mostly dissatisfied on the food services of the university. On the dimensional level, responsiveness got the highest negative gap which supports to the analysis made on the indicator level.

Meanwhile, the service improvement matrix made per indicator level, it is clearly emphasized that always ready and never too busy to respond to student's queries and requests should be given priority for improvement. As to unit level, dormitory fell on the first quadrant which means that dormitory services should also be given priority. As to dimensional level, responsiveness emerged as the most priority to be given with preferential attention for improvement.

The campus may utilize the results of this study towards improving its student services. Specifically, to improve responsiveness, the campus may provide additional personnel to provide speedy transactions especially during seasons where these services are needed the most by the students. The campus may institute reforms on how it delivers its canteen and dormitory services as these units were obviously underperforming units.

Since this study is limited only to one particular campus, the university may replicate this study with other campuses so as to validly compare the quality of the students' services across university. Moreover, other further studies may be conducted comparing quality of student services between private and public universities.

\section{REFERENCES}

Afridi, S. A., Khattak, A., \& Khan, A. (2016). Measurement of service quality gap in the selected private universities/institutes of peshawar using SERVQUAL Model. City University Research Journal, 6(1), 61-69.

Amin, M., Yahya, Z., Ismayatim, W. F. A., Nasharuddin, S. Z., \& Kassim, E. (2013). Service quality dimension and customer satisfaction: An empirical study in the Malaysian Hotel Industry. Services Marketing Quarterly, 34(2), 115-125.

Arangote, E. M. (2018). Assessment of student services in a State University for Policy Recommendations. The Normal Lights, 12(2), 145-167.

Arifin, M. H. (2018). The role of student support services in enhancing student persistence in the open university context: Lesson from Indonesia Open University. Turkish Online Journal of Distance Education, 19(3), $156-168$.

Bugnalen, A. P., Orsal, C. D., Sarmiento, J. L., \& Tomas, W. Q. (2009). A survey on trinity University of Asia Service Units: Implications to stakeholders satisfaction. The Trinitian Researcher, 2(1).

Cadag, C. P. (2017). Student services and their influence to student development. Asia Pacific Journal of Multidisciplinary Research, 5(3), 63-70.

Cayanan, C. D. (2017). Service quality of private tertiary education institutions in the province of Pampanga: A Gap Analysis. DLSU Research Congress 2017. Manila: De La Salle University.

Chui, T. B., Ahmad, M. S., Bassim, F., \& Zaimi, N. (2016). Evaluation of service quality of private higher education using service improvement matrix. Procedia - Social and Behavioral Sciences, 224(2016), 132-140.

Commision on Higher Education Memorandum Order No. 9, s. 2013. Enhanced policies and guidelines on student affairs and services.

Cronbach, L. J. (1951). Coefficient alpha and the internal structure of tests. Psychometrika, 16(3), 297-334.

Datta, K. S., \& Vardhan, J. (2017). A SERVQUAL-based framework for assessing quality of international branch campuses in UAE: A Management Students' Perspective. Sage Open, 7(1), 1-9.

Eisma, D. V. (2017). Extent of implementation and level of students' satisfaction on student services programs of DMMMSU. International Journal of Scientific \& Engineering Research, 8(9), 1648-1651. 


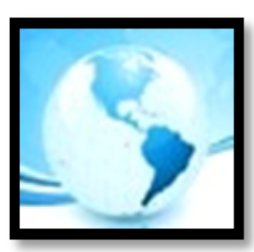

\section{MALAYSIAN ONLINE JOURNAL OF EDUCATIONAL MANAGEMENT (MOJEM)}

Ghotbabadi, A. R., Feiz, S., \& Baharun, R. (2015). Service quality measurements: A Review. International Journal of Academic Research in Business and Social Sciences, 5(2), 267-286.

Gregory, J. (2019). Applying SERVQUAL: Using service quality perceptions to improve student satisfaction and program image. Journal of Applied Research in Higher Education, 11(4), 788-799.

Hill, F. M. (1995). Managing service quality in higher education: The role of the student as primary consumer. Journal of Quality Assurance in Education, 3(3), 10-20.

Ibarrientos, J. A. R. (2015). Implementation and effectiveness of student affairs services program in One Polytechnic College. Asia Pacific Journal of Multidisciplinary Research, 3(5), 144-156.

Kalam, A., \& Mahonta, H. C. (2017). Measuring service gap of higher education in Bangladesh: A comparative study between public university and private university. IOSR Journal of Business and Management, 19(11), 49-55.

Kaur, S. (2016). Student support services in higher education: A student perspective. The International Journal of Indian Psychology, 3(3), 126-132.

Lodesso, S., van Niekerk, E., Jansen, C., \& Müller, H. (2018). Student satisfaction regarding service quality at Ethiopian Public Higher Education Institutions: A Case Study. Journal of Student Affairs in Africa, 6(2), 51-64.

Luna, G. L. (2015). Student services program of the Isabela State University. UNP Research Journal, 24(4), 45-58.

Milojević, R., \& Radosavljević, M. (2019). Assessment of higher education service quality: Integration of Servqual Model and AHP Method. Teme - Časopis za Društvene Nauke, 43(2), 557-577.

Misaii, H., \& Mohammadimehr, M. (2018). Evaluating the quality of educational services based on student's viewpoint according to SERVQUAL Model in the Faculty of Mathematical, Statistical and Computer Sciences at Tehran University. The Journal of Medical Education and Development, 12(4), 282-292.

Ojaghi, S., Rezaee, B., Naderi, N., \& Jafari, H. (2017). Entrepreneurship education service quality in universities based on servqual model. Malaysian Online Journal of Educational Management, 5(2), 60-74.

Ortiga, Y. (2018). Constructing a global education hub: The unlikely case of Manila. Discourse: Studies in the Cultural Politics of Education, 39(5), 767-781.

Parasuraman, A., Zeithaml, V. A., \& Berry, L. L. (1985). A conceptual model of service quality and its implications for future research. Journal of Marketing, 49, 41-50.

Parasuraman, A., Zeithaml, V. A., \& Berry, L. L. (1988). SERVQUAL: A multiple-item scale for measuring customer perceptions of service quality. Journal of Retailing, 64(1), 12- 40.

Rezaei, S., Karami Matin, B., Hajizadeh, M., Soroush, A., Mohammadi, Z., Babakhany, M., \& Jamshidi, K. (2017). Evaluating service quality in the higher education sector in iran: an examination of students' perspective. International Journal of Human Rights in Healthcare, 10(2), 146-155.

Rohini, R., \& Mahadevappa, B. (2006). Service quality in Bangalore Hospitals - An empirical study. Journal of Services Research, 6(1), 59-84.

Soares, M. C., Novaski, O., \& Anholon, R. (2017). Servqual model applied to higher education public administrative services. Brazilian Journal of Operations \& Production Management, 14(3), 338-349.

Tavakol, M., \& Dennick, R. (2011). Making sense of Cronbach's Alpha. International Journal of Medical Education, 2, 53-55.

Tefera, O., \& Govender, K. (2016). From SERVQUAL to HOTSPERF: Towards the development and validation of an alternate hotel service quality measurement instrument. African Journal of Hospitality, Tourism and Leisure, 5(4), 1-16.

Yarimoglu, E. K. (2014). A review on dimensions of service quality models. Journal of Marketing Management, 2(2), 79-93. 